\title{
The Effect of Academic Resilience and Social Support towards Student Involvement in Online Lecture
}

\author{
Rabiatul Adhawiyah ${ }^{1}$, Diah Rahayu ${ }^{2}$, Aulia Suhesty ${ }^{3}$ \\ 1,2,3 Department of Psychology, Faculty of Social and Political Sciences, Universitas Mulawarman
}

Submitted 22 August 2021 Accepted 25 September 2021 Published 30 October 2021

\begin{abstract}
The Covid-19 pandemic has made conventional lectures turn to online learning. The lecture system that is carried out by students is expected not to reduce student engagement in every lecture. Student involvement is due to the social support and academic resilience of students. This study aimed to determine the effect of academic resilience and social support on student engagement in online lectures. This study used a quantitative approach. The subjects of this study were 100 students of the Faculty of Social and Political Sciences, Mulawarman University who were selected using a simple random sampling technique. The data collection method used the scales of student engagement, academic resilience, and social support. The results showed that: (1) there is a significant effect of academic resilience and social support on student involvement in online lectures $(p<0.05)$ and had an influence contribution $(R 2)$ of $52 \%$; (2) there is a significant positive effect of academic resilience on student involvement in online lectures $(p<0.05)$; (3) there is a significant positive effect of social support on student involvement in online lectures $(p<0.05)$.
\end{abstract}

Keywords: academic resilience; online lecture; social support; student engagement

The Covid-19 pandemic has hit Indonesia since March 2020, resulting in a Formal Letter by the Ministry of Education and Culture Number 1 Year 2020 about the prevention of Covid-19 transmission. There was an order to hold online courses for educational institutions, including higher education. The online course is expected not to reduce students' understanding of the materials given by their instructors so that students can be involved in the online course (Firman \& Rahman, 2020; Widiyono, 2020).

In response to that, students need to remain involved in the online lectures so they can achieve learning targets despite learning in their own houses. Supported by a finding by Sholeh (2019), the main requirement to successfully achieve learning targets is student involvement. According to Qudsyi et al. (2016), student involvement can be defined as a form of student responsibility in terms of adherence towards academic rules, activeness in the learning process, and ability to interact effectively with related parties within the higher education which supports the learning process. A student who is doing online lectures still has responsibilities to their study. The responsibilities include adhering to the online course rules, being able to interact using online media, and actively participating in the online course proceeding.

A study done by Sulata and Hakim (2020) showed that the materials of theoretical courses taught online are difficult to understand, therefore the online course needs to be 
evaluated and the system must be improved so that students can understand the materials being delivered. Sadikin and Hamidah (2020) also revealed that the barrier to online lectures is that students are not monitored well; the internet connection and its expensive cost become challenges that need to be faced in doing online learning. Even then, the ability to solve problems and face challenges ideally can encourage students to participate and be interested to remain involved in online lectures.

Galugu and Baharuddin (2017) explained student involvement as the rate of participation and interest shown by students in academic activities. Students need to have the ability and effort to stay involved in the process of online lectures (Dharmayana, 2012; Mustika \& Kusdiyati, 2015). Student involvement by the ability to survive and face academic challenges during the online learning process; or also called academic resilience. This is in line with research finding from Amalia and Hendriani (2017) which showed that student involvement is influenced by academic resilience.

There needs to be a study that is relevant to the contemporary online lecture phenomenon especially related to the role of academic resilience of students in undergoing online lectures, because if students do not have adequate academic resilience, then the involvement in online lectures will decrease. The relevant study is useful for examining the dynamics of academic resilience and its effects in online lectures (Herman et al., 2011; Kumalasari \& Akmal, 2020). Academic resilience is a student's capability to survive during a difficult situation, attempting to rise from a slump and adapting positively to academic pressures and demands (Sari \& Indrawati, 2016). Students need to have academic resilience in facing various problems and pressures that they experience so that they can survive living in the higher education program (Hardiansyah et al., 2020).

According to Mustika and Kusdiyati (2015), student involvement is also affected by the supporting social environment. Social support may come in the forms of information provision, help, or even tangible aids obtained from social relationships (Gunarta, 2015). Handono and Bashori (2013) also explained that basically, social support is a relationship that is helpful when the student experiences difficulty; both in form of information or tangible help; so that the student will feel supported, cared for, and loved.

Social support is considered necessary for students during the Covid-19 pandemic right now since the courses are done online. Social support such as help obtained when facing difficulties can cause college students to feel cared for, appreciated, and loved (Handono \& Bashori, 2013; Rokhmatika \& Darminto, 2013). Reports related to students who experience difficulty in doing online lectures can be followed up, by providing more efficient supports from surrounding parties and sufficient internet connection (Taufiqurrahman, 2020). The result from a study by Rosa (2020) found that students who do not receive social support from parents and peers; such as not getting aid for an internet plan and indifferent peers; will be less motivated to participate in online lectures because of no internet connection and lack of information from peers. 
Based on the explanation about student involvement concerning academic resilience and social support, this study aimed to examine the role of academic resilience and social support towards student involvement within the setting of online lectures.

\section{Method}

\section{Participants}

The population in this study was 1437 students from the year 2018 and 2019. Active students from those years were able to participate in the study. When the online lecture was first implemented in the year 2018 and 2019 students were in the second and fourth semester respectively, thus became the population in this study. The determination of participants used simple random sampling. The sampling was done randomly, giving similar chance for population members to be the study participants, aided by SPSS. Since the population was large and disabling us to study all population members, we performed a calculation using the Slovin formula to determine the minimum sample size. The formula is as follows:

$n=\frac{N}{1+N(e)^{2}}$

Notes

$\mathrm{n}=$ Sample size

$\mathrm{N}=$ Population size

$\mathrm{E}=$ Precision value $(10 \%$ or $\mathrm{e}=0.1)$

$n=\frac{1437}{1+1437(0,1)^{2}}=94$

Based on the calculation, the recommended sample size for this study was at least 94. The researcher rounded up the sample size to 100 students.

\section{Research instruments}

Instruments used in the study employed a Likert scale with four alternative responses, namely: very appropriate, appropriate, inappropriate, very inappropriate. There were three scales used in the present study: 1) Student Involvement Scale with reliability coefficient of 0.813 and consists of 30 items (e.g.: "I participate in online course while doing other activities at home", "I easily get bored when doing online lecture", I pay attention to the learning materials given by instructor in online lecture without doing other activities to be more focused"); 2) Academic Resilience Scale with reliability coefficient of 0.757 and consists of 30 items (e.g.: "I find it hard to adjust to the change of the learning system which was previously in person to online", "I am able to face challenges in online lecture well", "I am happy to face 
challenges in online lecture even if it is difficult"); 3) Social Support Scale Scale with reliability coefficient of 0.780 and consists of 32 items (e.g.: "My classmates give me explanations of how to do tasks in online lecture", "My parents are indifferent about the online lecture that I am doing, thus making me feel ignored", "I am invited to online discussion to gain information about course assignments").

\section{Data analysis}

Data were analyzed using the descriptive test, assumption tests, and hypothesis test. The assumption test consists of normality test, linearity test, multicollinearity test, heteroscedasticity, and autocorrelation test. The hypothesis test in this study utilized multiple linear regression.

\section{Results}

Table 1.

Descriptive Analysis Results

\begin{tabular}{lccccc}
\hline \multicolumn{1}{c}{ Variable } & $\begin{array}{c}\text { Empirical } \\
\text { mean }\end{array}$ & $\begin{array}{c}\text { Empirical } \\
\text { SD }\end{array}$ & $\begin{array}{c}\text { Hypothetical } \\
\text { mean }\end{array}$ & $\begin{array}{c}\text { Hypothetical } \\
\text { SD }\end{array}$ & Status \\
\hline Student Involvement & 69.92 & 8.393 & 72.5 & 14.5 & Low \\
Academic Resilience & 54.23 & 6.260 & 57.5 & 11.5 & Low \\
Social Support & 77.19 & 8.825 & 75 & 15 & High \\
\hline
\end{tabular}

Table 2.

Categorization of Participant Scores

\begin{tabular}{cccc}
\hline Category & Student Involvement & Academic Resilience & Social Support \\
\hline Very High & $1 \%$ & $0 \%$ & $0 \%$ \\
High & $9 \%$ & $13 \%$ & $30 \%$ \\
Average & $65 \%$ & $51 \%$ & $54 \%$ \\
Low & $23 \%$ & $36 \%$ & $16 \%$ \\
Very Low & $2 \%$ & $0 \%$ & $0 \%$ \\
\hline Total & $\mathbf{1 0 0 \%}$ & $\mathbf{1 0 0} \%$ & $\mathbf{1 0 0} \%$ \\
\hline
\end{tabular}

Based on the participant scores, it was found that participants can be categorized as $1 \%$ as very high, $9 \%$ as high, $65 \%$ as average, $23 \%$ as low, and $2 \%$ as very low in student involvement in online lectures. Meanwhile, for academic resilience, $13 \%$ were categorized as high, $51 \%$ as average, and $36 \%$ as low. Moreover, $30 \%$ of students reported high social support, $54 \%$ reported average social support, and $16 \%$ reported low social support.

Before the hypothesis test, assumption tests were performed. First, the normality test using the Kolmogorov-Smirnov approach found normal distribution for the three variables $(p>0.05)$. The linearity test between student involvement and academic 
resilience found a linear relationship between the two $(F=1.426 ; p>0.05)$, and between student involvement and social support was also linear $(F=1.545 ; p>0.05)$.

Multicollinearity test between academic resilience and student involvement as well as social support and student involvement found VIF $1.712<10$ and tolerance $0.584<$ 1 , meaning that there was no multicollinearity. Autocorrelation test using Durbin-Watson approach showed $d$ value of $1.865, d L 1.634$, and $d U 1.715$. The scores was according to the guideline $1.715<1.634<2.285(d U<d<4-d U)$, thus there was no autocorrelation.

After performing assumption tests, a hypothesis test was conducted using multiple linear regressions. There were two models of multiple linear regressions, namely the full model and multilevel model regressions. The results of the analysis can be seen in Table 3 and 4 .

Table 3.

Result of Full Model Regression Analysis

\begin{tabular}{lcccc}
\multicolumn{1}{c}{ Variable } & $\boldsymbol{F}$ & Ftab & $\boldsymbol{R}^{2}$ & $p$ \\
\hline Student Involvement (Y) & & & & \\
Academic Resilience (X1) & 52.567 & 3.09 & 0.520 & 0.000 \\
Social Support (X2) & & & & \\
\hline
\end{tabular}

Based on table 3, it was found that academic resilience and social support play a significant role in student involvement $(F=52.567 ; p<0.05)$. Thus, the major hypothesis was accepted.

Table 4.

Results of Multilevel Model RegressionAnalysis

\begin{tabular}{lcccc}
\multicolumn{1}{c}{ Variable } & Beta & $T$ & Ttab & $p$ \\
\hline $\begin{array}{l}\text { Academic Resilience (X1) } \\
\text { Student Involvement (Y) }\end{array}$ & 0.534 & 5.802 & 1.984 & 0.000 \\
\cline { 2 - 5 } $\begin{array}{l}\text { Social Support (X2) } \\
\text { Student Involvement (Y) }\end{array}$ & 0.250 & 2.721 & 1.984 & 0.008 \\
\hline
\end{tabular}

Based on Table 4, there was a positive and significant influence of academic resilience towards student involvement $(T=5.802 ; p<0.05)$, meaning that the first minor hypothesis was accepted. The analysis also found a significant and positive influence of social support towards student involvement $(T=2.721, p<0.05)$, meaning that the second minor hypothesis was accepted. 


\section{Discussion}

According to the regression analysis, the major hypothesis in this study was accepted. There is an influence of academic resilience and social support on student involvement in online lectures. The contribution (R2) was 0.520 which means that academic resilience and social support simultaneously can predict student involvement in online lectures up to $52 \%$.

The descriptive statistics showed low student involvement in online lectures among participants in this study. Academic resilience was also found to be low, while social support was categorized as high. To conclude, participants in the study perceived a high level of social support.

The findings of this study are aligned with factors that are influencing student involvement according to Fredricks and McColskey (2012); i.e., the need for autonomy and competence that are indirectly related to academic resilience, as well as supporting social factors. A past study by Mustika and Kusdiyati (2015) also obtained a result in which student involvement is influenced by an internal factor (i.e., the need for autonomy) and an external factor (i.e., social support). Halimah et al. (2017) revealed that student involvement is impacted by an internal factor (i.e., self-assessment related to persistence in continuing academic activities, which is indirectly related to academic resilience) and an external factor (i.e., social context).

University students experience difficulty getting involved in online lectures because of the lack of facilities and learning skills (Rusman \& Nasution, 2020; Sholeh, 2019). The explanation is aligned with the results of the present study which, according to data categorization, found that student involvement in online lectures was low. A study done by Sulata and Hakim (2020) showed that the delivery of course materials in online lectures is difficult to understand. The study also found that students get many assignments but the time given is too short, therefore the students experience fatigue which leads to the difficulty of developing student involvement in online lectures.

The lack of involvement in online lectures can cause students to feel alienated in the earning process as well as feeling uncomfortable, thus doing the online lecture with indifference (Fikrie \& Ariani, 2019; Sholeh, 2019). The main requirement for students to succeed in achieving learning targets is the ability to be involved in their studies. It means that the students need to have a target academic score. To achieve that target score, students need to participate in the learning process, even if it is done online and they are facing obstacles.

Fikrie and Ariani (2019) explained that difficult academic activities in online lectures can hinder students to be involved in their learning process. It is supported by a later study by Sadikin and Hamidah (2020) which also explained that the disadvantages of online lectures include: the difficulty to supervise students, unstable internet connection, and the high price of an internet plan. The low student involvement is 
influenced by low academic resilience among them; because they would be able to solve online lecture obstacles if they have a high academic resilience.

Academic resilience is marked by student's capacity to perform adaptational responses towards academic situations, so they can face and deal with academic demands (Herman et al., 2011; Satyaninrum, 2014). Student's response to facing online lectures to remain involved in their learning is related to the processes of academic resilience. Aligned with a study by Skinner and Pitzer (2012) that unveiled how student involvement is a process of academic resilience done in daily life.

Based on the hypothesis testing using multilevel regression analysis, it was found that there is a significant and positive influence by academic resilience towards student involvement in online lectures. It means that the minor hypothesis in this study was accepted, or that academic resilience affects student involvement in online lectures. The results also explained that the higher the academic resilience, the higher the student involvement in online lectures would be and vice versa.

This finding is also aligned with prior research done by Amalia and Hendriani (2017) which also found that academic resilience has a significant positive influence on involvement. Such finding is also supported by another study by Ahmed et al. (2018). Based on descriptive statistics, it could be concluded that participants in this study had low academic resilience.

One of the factors that influence academic resilience according to Herrman et al. (2011) is a demographic factor, the student's age. In this study, participants were of age 19 to 22 years old. This age range is categorized as early adulthood and is known to face various obstacles. It was explained by Pattynama et al. (2019) that undergraduate students are likely to be between 19 to 23 years old, categorized as early adults, and commonly experience varied forms of challenges.

The difficulty occurred due to limited knowledge and the lack of readiness to deal with big changes in life, such as a new learning situation like an online lecture (Pattynama et al., 2019). Analysis of an open-ended question in the study's questionnaire revealed several common issues experienced by students, such as bad internet connection, not understanding the course materials, poor time management, short deadlines for assignments, laziness, expensive internet plan, unfit laptop and smartphone, unsupportive surrounding environment, difficulty to focus, and boredom.

According to the study finding, there were few ways that the students do to overcome problems during online lectures. Most of the study participants looked for better internet signals at other places. Other things that they would do include adapting to the new learning mode, sharing stories with peers, learning to be independent, and trying to stay focus partaking in online lectures. However, some participants resignedly accepted their online lecture situation, silently waiting for the connection to be stable again, and even choosing not to participate in online lectures. 
The way students face problems in online lectures needs to be examined because it is a part of student's academic resilience. Based on a study done by Sari et al. (2020), academic resilience in university students must be kept in mind as low academic resilience can lead to restlessness and difficulty to cope with problem arises from the online lecture. This difficulty can cause students to be less involved in their online lectures. This explains how academic resilience can influence student involvement within the context of online learning.

During the online lectures, students will also be more involved if receiving support from their social environment. This is in line with Mustika and Kusdiyati's (2015) finding of social support as a factor that influences social support. Sara and Idris (2020) explained that social support is illustrated by help provision for students in facing problems. The help can be in the form of advice to students, guidance in the online lecture, as well as material aid such as internet plan to access online lectures.

Based on the multiple regression analysis, social support significantly affects student involvement in online lectures. It means that the minor hypothesis in this study was accepted. The result explained that the higher the social support, the higher student involvement in online lectures would be, and vice versa.

The finding is aligned with a previous study by Galugu and Baharuddin (2017) which also found a positive relationship between social support and involvement. Another preceding study by Wisuda (2018) also showed similar results. In addition, the study by Rahman and Rusli (2020) also proved the significant positive influence of social support towards involvement.

According to the descriptive data, it can be concluded that the study's participants received high social support. Social support refers to information and materials provisions that make students feel they are attended to (Gunarta, 2015). Students who are given helpful information or materials during online lectures (e.g.: information about course schedule or internet plan support) cause students to feel noticed and cared for. The social support will cause the student to participate in the online lecture which would lead to involvement in the learning activities.

In line with a finding from a study by Rosa (2020), students can participate in online lectures because of attention and support from parents, in the form of providing internet connection for the learning activities. Students who also receive support and encouragement from peers would be able to discuss their assignments and remind each other about course schedules. The results of a study by Rosa (2020) further explained that students who did not receive social support from parents and peers will feel unmotivated to participate in online lecture

The present study also obtained a finding through an open-ended question about the source of social support received by students during the online lecture process. It was found that the majority of participants received social support from parents and peers. It is in line with previous research by Galugu and Baharuddin (2017), which revealed that 
social support from parents and peers can increase involvement. Another research that showed similar results is by Astuti and Hartati (2013). Further, the study explained that supports from peers come in the form of attention and encouragement when doing the online lecture program. Therefore, students would be able to avoid boredom and helplessness to be involved in the online lecture process (Astuti \& Hartari, 2013).

The provision of support given by parents to the students to perform their academic duties is caused by parents' expectations for their children to finish their education on time and not prevented from achieving their degrees even though the courses are conducted online. It is in line with a previous study done by Mulyana et al. (2020) that students might be involved in online lectures due to receiving parents' support.

Astuti and Hartati (2013) also explained that student who has a close relationship with their parents will cause them to perceive that parents would help them when experiencing difficulties without even being asked. Previous studies have shown that a factor affecting social support is perception (Handono \& Bashori, 2013; Rokhmatika \& Darminto, 2013). Students who perceive their social support positively will receive the support properly and utilize them according to their needs. It shows how social support can influence student involvement in online lectures.

\section{Conclusion}

Based on the study that has been conducted, it can be concluded that student involvement in online lectures tends to be low. Academic resilience during online lectures tends to be low, whilst the social support that students receive is high. Then, there is a significant and simultaneous influence of academic resilience and social support towards student involvement in online lectures. Academic resilience has a significant and positive role in student involvement within the context of online learning. Social support also has a significant and positive influence on the involvement of students in online lectures.

\section{Suggestion}

Students are expected to develop tenacity; such as: exerting efforts, working hard, not easily giving up, following the academic objectives rigorously, adhering to academic regulations, thinking about problem resolution by formulating either big or small problems, and dealing with academic difficulty by designing timeline for the online course. Students also need to provide support to each other when facing difficult situations and be able to accept the support. The support that can be done such as sharing information related to the online course materials, reminding each other about the online course schedule, motivating each other, and discussing course materials albeit online.

Parents are expected to provide support in the form of positive appreciation such as expressing their pride when the student can achieve satisfactory academic scores so 
that they would be more motivated to participate in online lectures, as well as giving motivation if the student does not achieve the online course targets optimally. Parents can also offer tips and advice to immediately finish their tasks and guide students to attend online lectures on time.

Future researchers also need to develop a more specific study, such as student involvement in online lectures, particularly in practical courses. Future researchers can also perform a tryout of the study measurements in the data collection process. It will unveil the scale validity so that the data obtained will be more accurate and in line with the study's objective.

\section{Acknowledgement}

This research was conducted as the final project in the Department of Psychology at Mulawarman University. The author thanks the participants for the willingness to participate in the study.

\section{Authors' contribution}

RA as the main author designed the study, performed data collection, analyzed the data, and wrote the manuscript. DA as the main supervisor provided insights and feedback related to the issues of student involvement in online lecture, the theoretical study, and the research method. AU as the second supervisor provided overview of academic resilience and social support in university students during online lecture in the introduction section, and examined the measurement used in this study.

\section{Conflict of interest}

The authors declare no conflict of interest in this study.

\section{Funding}

The study used personal fund.

\section{orCid ID}

Rabiatul Adhawiyah 0000-0002-5913-2695

Diah Rahayu 0000-0003-3579-9708

Aulia Suhesty 0000-0002-7216-2063

\section{References}

Ahmed, U., Umrani, W. A., Qureshi, M. A., \& Samad, A. (2018). Examining the links between teachers support, academic efficacy, academic resilience, and student engagement in bahrain. International Journal of Advanced and Applied Sciences, 5(9), 39-46. https://doi.org/10.21833/ ijaas.2018.09.008

Amalia, R., \& Hendriani, W. (2017). Pengaruh resiliensi akademik dan motivasi belajar terhadap student engagement pada santri mukim pondok pesantren nurul Islam karangcempaka sumenep. Jurnal Psikologi Pendidikan dan Perkembangan, 6, 1-13. Retrieved from http://url.unair.ac.id/5e974d38 
Astuti, T. P., \& Hartati, S. (2013). Dukungan sosial pada mahasiswa yang sedang menyusun skripsi (studi fenomenologis pada mahasiswa fakultas psikologi undip). Jurnal Psikologi Undip, 12(1), 69-81. https://doi.org/10.14710/jpu. 12.1

Dharmayana, I. W. (2012). Keterlibatan siswa (student engagement) sebagai mediator kompetensi emosi dan prestasi akademik. Jurnal Psikologi, 39(1), 76-94. https://doi.org/10.22146/jpsi.6968

Fikrie \& Ariani, L. (2019). Keterlibatan siswa (student engagement) di sekolah sebagai salah satu upaya peningkatan keberhasilan siswa di sekolah. Prosiding Seminar Nasional \& Call Paper, 103-110. Retrieved from http://fppsi.um.ac.id/wpcontent/uploads/2019/07/13

Firman \& Rahman, S. R. (2020). Pembelajaran online di tengah pandemi covid-19. Indonesian Journal of Educational Science, 2(2), 81-89. https://doi.org/10.31605/ijes.v2i2.659

Fredricks, J. A., \& McColskey, W. (2012). The measurement of student engagement: a comparative analysis of various methods and student self-report instruments. In S. L. Christenson, A. L. Reschly, \& C. Wylie, Handbook of Research on Student Engagement. (pp. 763-782). https://doi.org/10.1007/978-1-4614-2018-7_37

Galugu, N. S., \& Baharuddin. (2017). Hubungan antara dukungan sosial, motivasi berprestasi dan keterlibatan siswa di sekolah. Journal of Islamic Education Management, 3(2), 53-64. Retrieved from http://jurnal.radenfatah. ac.id/index.php/El-idare

Gunarta, M. E. (2015). Konsep diri, dukungan sosial dan penyesuaian sosial mahasiswa pendatang di Bali. Persona: Jurnal Psikologi Indonesia, 4(02), 183-194. https://doi.org/ 10.30996/persona.v4i02.560

Halimah. L., Kusdiyati. S., \& Susandari. (2017). Pengaruh konteks teman sebaya terhadap keterlibatan belajar dengan mediator self-system proses. Jurnal Ilmiah Psikologi, 4(2). 265-274. https://doi.org/10.15575/psy.v4i2.1612

Handono, O. T., \& Bashori, K. (2013). Hubungan antara penyesuaian diri dan dukungan sosial terhadap stres lingkungan pada santri baru. Empathy, 1(2), 79-89. Retrieved from https://media.neliti.com/media/ publications/241983

Hardiansyah., Putri, A. P., Wibisono, M. D., Utami, D. S., \& Diana. (2020). Penyusunan alat ukur resiliensi akademik. Psikostudia, 9(3), 185-194. https://dx.doi.org/10.30872/psikostudia.v9i3.3159

Herrman, H., Stewart, D. E., Diaz-Granados, N., Berger, E. L., Jackson, B., \& Yuen, T. (2011). What is resilience?. The Canadian Journal of Psychiatry, 56(5), 258-265. https://doi.org/10.1177/070674371105600504

Kumalasari, D., \& Akmal, S. Z. (2020). Resiliensi akademik dan kepuasan belajar daring di masa pandemi covid-19: peran mediasi kesiapan belajar daring. Persona: Jurnal Psikologi Indonesia, 9(2), 12-23. https://doi.org/10.30996/persona.v9i2.4139 
Mulyana, M., Rainanto, B. H., Astrini, D., \& Puspitasari, R. (2020). Persepsi mahasiswa atas penggunaan aplikasi perkuliahan daring saat wabah covid-19. Jurnal Analisis Sistem Pendidikan Tinggi, 4(1), 47-56. https://doi.org/10.36339/jaspt.v4i1.301

Mustika, R. A., \& Kusdiyati, S. (2015). Studi deskriptif student engagement pada siswa kelas XI IPS di SMA Pasundan 1 Bandung. Prosiding Psikologi, 1(2), 244-251. https: //dx.doi.org/10.29313/.v0i0.1204

Pattynama, P. C., Sahrani, R., \& Heng, P. H. (2019). Peran regulasi diri dalam belajar dan keterlibatan akademik terhadap intensi mengundurkan diri dengan resiliensi sebagai mediator. Jurnal Muara Ilmu Sosial, Humaniora, dan Seni, 3(2), 307-317. https://doi.org/10.24912/jmishumsen.v1i1.5629

Rahman, I., \& Rusli, D. (2020). Pengaruh dukungan sosial teman sebaya terhadap. Jurnal Riset Psikologi, 1(1), 1-11. https://dx.doi.org/10.24036/ jrp.v2020i1.7967

Rokhmatika, L., \& Darminto, E. (2013). Hubungan antara persepsi terhadap dukungan sosial teman sebaya dan konsep diri dengan penyesuaian diri di sekolah pada siswa kelas unggulan. Jurnal BK UNESA, 1(1), 149-157. Retrieved from https://jurnalmahasiswa.unesa.ac.id/index.php/jurnal-bk-unesa

Rosa, N. N. (2020). Hubungan dukungan sosial terhadap motivasi belajar daring mahasiswa pada masa pandemi covid-19. Tanjak: Journal of Education and Theaching, 1(2), 147-153. https://doi.org/10.35961/ tanjak. v1i2.146

Rusman, A. A., \& Nasution, F. (2020). Deskripsi kebahagiaan belajar mahasiswa BKI pada masa pandemi covid-19. AL-Irsyad: Jurnal Pendidikan dan Konseling, 10(1), 1-7. Retrieved from http://jurnal.uinsu.ac.id/index.php/al-irsyad

Sadikin, A. \& Hamidah, A. (2020). Pembelajaran daring di tengah wabah Covid-19. Biodik: Jurnal Ilmiah Pendidikan Biologi, 6(2), 214-224. https://doi.org/10.22437/bio.v6i2.9759

Satyaninrum, I. R. (2014). Pengaruh school engagement, locus of control, dan dukungan sosial terhadap resiliensi akademik remaja. Tazkiya Journal of Psychology, 2(1), 1-20. https://doi.org/10.15408/tazkiya.v2i1.10749

Sara, E. P., \& Idris, S. (2020). Pengaruh dukungan sosial dan karir efikasi diri terhadap pilihan karir dengan eksplorasi karir sebagai pemediasi pada mahasiswa S1 fakultas ekonomi dan bisnis universitas syiah kuala. Jurnal Ilmiah Mahasiswa Ekonomi Manajemen, 5(1), 98-113. https://doi.org/10.24815/jimen.v5i1.14176

Sari, P. K. P., \& Indrawati, E. S. (2016). Hubungan antara dukungan sosial teman sebaya dengan resiliensi akademik pada mahasiswa tingkat akhir jurusan $x$ Fakultas Teknik Universitas Diponegoro. Empati,5(2), 177-182. Retrieved from https: //ejournal3.undip.ac.id/index.php/empati/article/view/14979

Sari, S. P., Aryansah, J. E., \& Sari, K. (2020). Resiliensi mahasiswa dalam menghadapi pandemi covid-19 dan implikasinya terhadap proses pembelajaran. Indonesian Journal of Guidance and Counseling: Theory and Application, 9(1), 17-22. https://doi.org/10.15294/IJGC.V9I1.38674 
Sholeh, M. (2019). Korelasi penggunaan internet sebagai sumber belajar dan kemandirian belajar terhadap keterlibatan mahasiswa dalam proses pembelajaran di uin antasari Banjarmasin. Journal of Applied Linguistics and Islamic Education, 3(1), 138164. https://dx/doi.org/10.33754/ jalie.v3i1.226

Skinner, E. A., \& Pitzer, J. R. (2012). Developmental dynamics of student engagement, coping, and everyday resilience. In S. L. Christenson, A. L. Reschly, \& C. Wylie, Handbook of Research on Student Engagement (pp. 21-44). https://doi.org/10.1007/9781-4614-2018-7_2

Sulata, M. A., \& Hakim, A. A. (2020). Gambaran perkuliahan daring mahasiswa ilmu keolahragaan unesa di masa pandemi covid-19. Jurnal Kesehatan Olahraga, 8(3), 147156. Retrieved from https:// jurnalmahasiswa.unesa.ac.id/index.php/jurnalkesehatan-olahraga/article/view/34491

Taufiqurrahman, M. (2020). Perkuliahan daring mata kuliah ilmu pendidikan Islam pada masa darurat covid-19. Ta'dibuna: Jurnal Pendidikan Islam, 9(2), 213-224. https://dx/doi.org/ 10.32832/tadibuna.v9i2.3151

Qudsyi, H., Sa'diyah, S. K., \& Mahara, R. (2016). Student engagement among high-school students in Indonesia: prediction of family functioning and peer support. International Conference on Education, Psychology, and Social Sciences, 1(1), 247266. Retrieved from https://www.researchgate.net/publication/323357524

Widiyono, A. (2020). Efektifitas perkuliahan daring (online) pada mahasiswa PGSD di saat pandemi covid-19. Jurnal Pendidikan, 8(2), 169-177. https://doi.org/10.36232/ pendidikan.v8i2.458

Wisuda, A. K. (2018). Hubungan antara dukungan sosial dengan student engagement pada siswa di sekolah inklusi Kota Salatiga. Published manuscript. Fakultas Psikologi dan Ilmu Sosial Budaya, Universitas Islam Indonesia. Retrieved from: //dspace.uii.ac.id/handle/123456789 